\title{
Effects of starvation and realimentation on the performance of pregnant ewe
}

\author{
Eniolorunda $00^{1}$, AIO Adewale ${ }^{2 *}$ \\ ${ }^{1}$ Department of Animal Production, Faculty of Agricultural Production and Renewable Resources, College of \\ Agricultural Sciences, Olabisi Onabanjo University, Ogun state, Nigeria; ${ }^{2}$ Department of Animal Sciences, \\ Faculty of Agriculture, University of Ibadan, Oyo State, Ibadan, Nigeria
}

\begin{abstract}
Twenty pregnant ewes were used in this study. Ten pregnant ewes with a mean live weight of $19.37 \mathrm{Kg}$ \pm 0.87 served as the control animals, the others with an average live weight of $19.50 \mathrm{Kg} \pm 0.37$ were starved for 7 days to study the reproductive performances, feed intake and appetite, body weight and rate of recovery in the animals. Test animals were starved during the first week of the last trimester of pregnancy (16th week). Starvation did not cause any significant changes in gestation length, which was within the normal range of 146 to 149 days. A live weight loss of $3.20 \%$ was observed during the starvation period. As the starvation progressed, the animals became weak and dull in appearance. Their hairs became loose and tended to fall out. Moreover, as from the 5th day of starvation, they were in a semi-comatose condition and were observed to sway when made to walk. Starvation also resulted in lower $(\mathrm{P}<0.05)$ birth weight of lambs:2.05 $\pm 0.05 \mathrm{~kg}$ for lambs from starved ewes compared to $2.25+$ $0.10 \mathrm{Kg}$ for lambs from the control pregnant ewes. However, subsequent growth of all lambs produced during the study was not appreciably affected. On resumption of ad libitum feeding appetites as Dry matter intake was low and erratic for 4-6 days. There after feed intake returned to normal with a marked increase in live weight gain.
\end{abstract}

Key words: starvation, realimentation, performance, pregnant ewes Bangladesh Animal Husbandry Association. All rights reserved.

Bang. J. Anim. Sci. 2016. 45 (2): 35-40

\section{Introduction}

In Nigeria, ruminants have recently been subjected to periods of low feed intake because of high prices of cereals, grains and acute shortage of fodder. In addition to the inconsistent seasonal variations in feed supply, animals are sometimes subjected to periods of starvation which occur during transportation of these animals from one part of the country to the other. Fasting causes profound changes in the ruminant flora (Esugbohungbe and Adeleye, 2003).If the fasting period is too protracted, it may adversely affect the appetite so that when food is again made available it is taken less readily(Poindron et. al., 2007). Studies (Esugbohungbe and Adeleye, 2003) on effect of 48 hrs food deprivations on subsequent feed intake on behaviour of sheep showed that fewer males were eating in the first day following deprivation and feeding behaviour was highly variable.
The plane of nutrition of the breeding ewe during the first 100 days of pregnancy has little effect upon the birth weight of lambs, mammary development in ewe, and initiation of lactation and persistence of lactation (Robinson, 1990).Evidence mostly from trials carried out in pens have shown that birth weight and subsequent growth of the lamb, length of gestation, initiation of lactation and persistence of lactation are considerably affected by the plane of nutrition during this period (Fahey et al., 2005; Vonnahme et al., 2002). Cattle, sheep, goat, camels are usually transported by rail or roads within Nigeria or from neighbouring countries like Chad or Niger Republic to Nigeria. The period of transport varies and could last for a minimum of our days. The animals, to a large extent do not have access to food or water (Eniolorunda et al., 2009). There has been no attempt to document the effect of such period of starvation on pregnant and lactating animals.

\footnotetext{
*Corresponding author: olueniolorunda@gmail.com
} 
The present study therefore, investigated the effect of starvation and performance (including pregnancy, gestation period, parturition and birth weight of lambs). It also determined feed intake and appetite, body weight, rate of recovery from starvation and other performance characteristics in West African dwarf Sheep.

\section{Materials and Methods}

\section{Study location}

The study was carried out at the sheep unit of the college of Agricultural Sciences, Olabisi Onabanjo University, Yewa campus, Ayetoro. Ayetoro is located in latitude $7^{0} 15^{1} \mathrm{~N}$ and longitude $3^{0} 3^{1} \mathrm{E}$ in deciduous derived savannah zone of Ogun State. Climate is sub humid tropical with an annual rainfall of $763.3 \mathrm{~mm}$ in 74 days. Maximum temperature varies between $29^{\circ} \mathrm{C}$ during the peak of wet season (Feb and March) and $34^{\circ} \mathrm{C}$ during the dry season, mean annual relative humidity is 81\% (Onakomaya et.al., 1992).

\section{Management of experimental animals}

Thirty one (31) pubertal West African Dwarf ewes, whose weight ranged between 16.80$18.75 \mathrm{~kg}$, were used in the study. They were purchased from smallholder's farm at IganOkoto, a village near the University town of Ayetoro, Ogun State, Nigeria. Deworming was performed using ivomec intramuscular injection at the rate of $1 \mathrm{ml}$ per $50 \mathrm{~g}$ weight; also ewes were vaccinated against Peste des Petite ruminant (PPR) at the rate of $1 \mathrm{ml}$ per $50 \mathrm{~kg}$ weight of animal. Prophylactic antibiotic treatment with (oxytetracycline injection, tylosin, streptomycin and penicillin) were applied, the quarantine and adjustment lasted for a period of two weeks. During this period animal were groupfed with giant star grass and dried cassava peels, clean and cool water were supplied without restriction.

\section{Estrus synchronization}

Two injections of prostaglandin $\left(\mathrm{PGF}_{2 a}\right)$ were given to each ewe 10 days apart intramuscularly at the rate of $1 \mathrm{ml}$ per $46 \mathrm{~kg}$ of animal body weight, also animals were checked for estrus three days after the last injection and were performed natural mating at day 7 after the application of prostaglandin $\mathrm{PGF}_{2 a}$, by West African Dwarf rams. Rams were retained with ewes for 5 days before they were moved into the pens (Lauderdale, 1972; Louis et al., 1972; Rowson et al., 1972, King and Roberton 1974, Roche, 1977).

\section{Management of experimental pregnant ewes}

A total of twenty (20) ewes having eleven week pregnancy, whose weight ranged between 18.50 to $21.25 \mathrm{~kg}$ were selected for this study. They were divided into two groups on weight basis and were randomly assigned to each group. Animal in group $\mathrm{C}$ served as control while those in group $\mathrm{T}$ served as test animals. They were housed in a row of disinfected individual pens, each approximately $2 \mathrm{~m} \times 1 \mathrm{~m}$ with a wooden gate, $1.2 \mathrm{~m}$ high. The pens were heavily covered with wood shaving to provide a dry bed and prevent pneumonia. Soiled wood shaving were usually removed every other day, or anytime when found to be wet and replaced with fresh ones.

Table 1. Composition of concentrate mix

\begin{tabular}{lll}
\hline Ingredient & $\%$ & CP \% \\
\hline Corn meal & 55.00 & 3.90 \\
Palm kernel meal & 20.00 & 3.80 \\
Groundnut cake & 9.65 & 4.42 \\
Brewers Dried Grain & 15.00 & 3.89 \\
Minovit super & 0.10 & - \\
Salt & 0.25 & - \\
Total & 100.00 & 16.01 \\
\hline
\end{tabular}

\section{Feed preparations and feeding regimes}

The feed used throughout the period of the experiment was prepared in the Olabisi Onabanjo University feed Depot. The ingredient composition is shown in Table 1.

Table 2: Proximate composition of experimental diet

\begin{tabular}{lll}
\hline & Concentrate mix & $\begin{array}{l}\text { Cynodon } \\
\text { nlemfuensis }\end{array}$ \\
\hline Dry matter & 93.61 & 42.23 \\
Crude protein & 19.93 & 8.46 \\
Crude Fibre & 2.64 & 31.54 \\
Ether Extract & 1.13 & 1.17 \\
Nitrogen Free Extract & 75.73 & 52.10 \\
Ash & 0.57 & 6.73 \\
Organic matter & 99.43 & 93.27 \\
Gross Energy & 802.45 & 445.41 \\
(kcal/100g) & & \\
\hline
\end{tabular}

The amount of concentrate offered was adjusted so that the refusal was about $10 \%$ of the amount 
offered. Young succulent Giant Star Grass which was harvested and stored to wilt for $24 \mathrm{hrs}$, was also fed ad libitum. Fresh water was made available all the time. The feed (concentrate and grass) offered daily to each animal was usually weighed out and the quantity of feed consumed daily was determined by weighing the remnant every morning. The difference between the daily offer and the refusal represented the feed intake for the previous day.

\section{Weight changes}

The live weights of the individual animal were recorded at the beginning of the experiment, and subsequently at weekly intervals. These weights were normally taken at about 07.30 AM before feeding. All lambs were weighed within $1 \mathrm{hr}$ of birth and thereafter at weekly intervals.

\section{Analytical procedure}

The concentrate feed sample and giant star grass were dried at $105^{\circ} \mathrm{C}$ to constant weight and Table 3. Effect of starvation and realimentation on feed intake $(\mathrm{g})$ in pregnant ewes

\begin{tabular}{lllll}
\hline Week & $\begin{array}{l}\text { Pregnancy } \\
\text { (wks) }\end{array}$ & Period & $\begin{array}{l}\text { Mean feed intake }(\mathbf{g}) \\
\text { Test animal group }\end{array}$ & Control \\
\hline $\mathbf{0}$ & 11 & Pre-starvation & $865.43 \pm 12.86$ & $911.65 \pm 63.55$ \\
$\mathbf{1}$ & 12 & $941.66 \pm 36.66$ & $943.57 \pm 32.14$ \\
$\mathbf{2}$ & 13 & $1010.71 \pm 43.57$ & $1017.86 \pm 26.43$ \\
$\mathbf{3}$ & 14 & $1005.28 \pm 47.85$ & $1027 \pm 27.14$ \\
$\mathbf{4}$ & 15 & & $980.28 \pm 47.85$ & $987.85 \pm 11.71$ \\
$\mathbf{5}$ & 16 & $992.14 \pm 52.97 \mathrm{a}$ & $0.00 \pm 0.00 \mathrm{~b}$ \\
& & Starvation & $1044.00 \pm 60.00$ & $540.00 \pm 12.00$ \\
& & Realimentation (1st wk of re-feeding) & $245.00 \pm 15.00$ \\
& & & $960.00 \pm 30.00$ & $445.00 \pm 15.00$ \\
& & $985.00 \pm 25.00$ & $595.00 \pm 35.00$ \\
& & $995.00 \pm 75.00$ & $695.00 \pm 35.00$ \\
& & $1005.00 \pm 5.00$ & $775.00 \pm 75.00$ \\
& 17 & $1039.00 \pm 95.00$ & $810.00 \pm 70.00$ \\
$\mathbf{6}$ & 18 & $970.00 \pm 10.00$ & $586.43 \pm 18.67 \mathrm{~b}$ \\
$\mathbf{7}$ & 19 & $998.00 \pm 32.67 \mathrm{a}$ & $952.21 \pm 27.78$ \\
$\mathbf{8}$ & 20 & $990.28 \pm 37.14$ & $1171.43 \pm 30.00$ \\
$\mathbf{9}$ & 21 & $1122.50 \pm 81.79$ & $1124.35 \pm 12.78$ \\
$\mathbf{1 0}$ & & $1104.28 \pm 7.14$ & $1057.00 \pm 17.29$ \\
\hline
\end{tabular}

Figure in italics show the first week of refeeding in days. Superscript $a, b$, means on the same row with different superscript are significantly $(p<0.05)$ different. For instance, when ration was supplied, the test pregnant ewes ate practically nothing. However, as from the second week of realimentation, the difference in average feed intake of the test group was found to be insignificant $(p>0.05)$ when compared to control group. milled. Five grams each of milled samples of feed and giant star grass were taken for proximate analysis, which was done according to AOAC (2002). Analysis of variance (ANOVA) using (SAS, 2002) and mean comparison was performed with Duncan Multiple Range Test (DMRT).

\section{Results and Discussion}

\section{Feed intake}

The ingredient and the chemical compositions of the concentration mix and giant star grass used are shown in Tables 1 and 2. Table 3showed the mean weekly intake $(\mathrm{g})$ for the pregnant ewes. There was no consistent pattern in the intake of animals understudy. Feed intake increased gradually as from the start of the experiment without any significant difference $(P>0.05)$ between the control and the test animals during the pre-starvation period. 
At the end of the starvation period however, the average feed intake in the control animals showed little increases over those recorded during the pre-starvation period. Apart from the fact that no feed was offered to test animals during the starvation period, feed intake during the first weeks of realimentation period were significantly low $(P<0.05)$, compared either to what was consumed prior to starvation or to those of the control animals. On resumption of ad libitum feeding, appetite and dry matter intake were low and erratic for 4 to 6 days and thereafter return to normal with a marked increase in live weight gain.

Weight changes and general conditions Average live weight of animals on the control and test groups is shown in Table 4. At the beginning of the study, the experimental animals were in good condition with average live weight of 19.50 $\pm 0.37 \mathrm{~kg}$. Also the mean live weight of the control animals was $19.37 \pm 0.87 \mathrm{~kg}$. In all the animals, there were gradual and successive gains in live weight up to the $15^{\text {th }}$ week of pregnancy

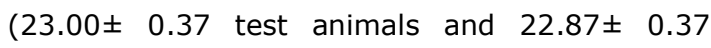
control animals). Starvation resulted in a decrease of $1.22 \mathrm{~kg}$ (3.20\%) weight after the 7 day starvation period. On the other hand the live weight of the control animals increased $(1.30 \mathrm{~kg}$ which is $4.06 \%$ ) during the same period.
The pattern of live weight loss as reported above compared favourably to $8.2 \%$ has observed in goat (Rook, 2000; Laporte-Broux et al., 2011) during a 90days feed restriction trial. Also, the pattern appeared similar to those observed (Kirton et al., 1972) with initial live weight reduced by $13 \%$ and $10 \%$ respectively after 4 days fast and further reduced to $15 \%$ (Kirton et al., 1972) after 8 days starvation. (The difference in observation might be due to the fact that while sheep was used in the present stud, cattle were used by these researchers. During the period of starvation, the test animals became weak and spend much time lying down. Also they were not scared of human beings during this period of pronounced dullness. Their hair became loose and ended to fall out. They were in a semicomatose condition as from the $5^{\text {th }}$ day of starvation. They were observed to sway when made to walk and walked into objects in their paths. These animals however recovered, and by the end of the experiment all the ewes appeared normal. The phenomenon reported in the present study was in agreement with the observation of (Robinson et.al., 1999; Dwyer, 2008) authors reported that when a female sheep has had inadequate feed intake or restricted diet during pregnancy, negative consequences are observed, as thin and weak lamb, low milk yield and an increase in postnatal mortality.

Table 4. Mean weekly weight $(\mathrm{kg})$ of pregnant ewe before, during and after starvation

\begin{tabular}{lllll}
\hline Period of Starvation & Week & Pregnancy (wks) & Control & Test \\
\hline Before & 0 & 11 & $19.37 \pm 0.87$ & $19.50 \pm 0.37$ \\
& 1 & 12 & $20.17 \pm 0.87$ & $20.20 \pm 0.12$ \\
& 2 & 13 & $21.12 \pm 0.87$ & $21.25 \pm 0.12$ \\
& 3 & 14 & $22.04 \pm 0.62$ & $22.00 \pm 0.37$ \\
During & 4 & 15 & $22.87 \pm 0.37$ & $23.00 \pm 0.37$ \\
After & 5 & 16 & $24.17 \pm 0.12^{\mathrm{a}}$ & $21.78 \pm 0.50^{\mathrm{b}}$ \\
& 6 & 17 & $25.32 \pm 0.05^{\mathrm{a}}$ & $22.58 \pm 0.87^{\mathrm{b}}$ \\
& 7 & 18 & $26.52 \pm 0.05^{\mathrm{a}}$ & $23.83 \pm 0.87^{\mathrm{b}}$ \\
& 8 & 19 & $27.97 \pm 0.62^{\mathrm{a}}$ & $25.25 \pm 0.75^{\mathrm{b}}$ \\
& 9 & 20 & $29.72 \pm 0.62^{\mathrm{a}}$ & $26.80 \pm 0.62^{\mathrm{b}}$ \\
& 10 & 21 & $31.24 \pm 0.62^{\mathrm{a}}$ & $28.28 \pm 0.50^{\mathrm{b}}$ \\
& & 22 & $27.44 \pm 0.62^{\mathrm{a}}$ & $24.63 \pm 0.37^{\mathrm{b}}$ \\
\hline
\end{tabular}

Superscripts $a, b$ mean on the same row with different superscripts are significantly $(p<0.05)$ different. 
Another fall in live weight of the pregnant ewes was again noted at lambing. For instance, towards parturition all the test pregnant ewes became emaciated and weak. They spent most of the time lying down and as if it was a rule, only stood up when eating their feed or when being weighed. The body condition of test pregnant ewes observed during the trial was similar to those reported by (Dwyer et al., 2003). The authors reported that lambs born from under nourished mother took longer time to stand and nurse than lamb from the well fed group. Despite this phenomenon, normal lambing was witnessed in both groups of ewes.

\section{Realimentation and appetite}

When feeding was resumed after 7-day starvation period, the test pregnant ewes had difficulty in eating rapidly for the first 3days. It has been postulated (Mc Donald et.al., 1995) that the longer the starvation period, the less rapid the sheep eat during earlier days of realimentation. Ewes after lambing showed marked increase in intake reaching a peak at about a month after lambing. The present result and those of Esugbohungbe and Adeleye, 2003 followed the same pattern. The increase in intake that occurs after parturition was explained to be due to the depression in consumption in late pregnancy. Furthermore, intakes appeared to be $30-50 \%$ higher during lactation than in late pregnancy in this study. This observation is in agreement with those of Snowder and Glimp (1991) on standard diet.

Table 5. Mean weekly $(\mathrm{kg})$ of lambs from the control and test pregnant ewes

\begin{tabular}{lll}
\hline Age (wks) & Control & Test \\
\hline $\mathbf{0}$ & $2.25 \pm 0.01$ & $2.05 \pm 0.05$ \\
$\mathbf{1}$ & $3.63 \pm 0.02$ & $3.32 \pm 0.97$ \\
$\mathbf{2}$ & $4.60 \pm 0.00$ & $4.37 \pm 0.28$ \\
$\mathbf{3}$ & $5.37 \pm 0.12$ & $5.35 \pm 0.15$ \\
$\mathbf{4}$ & $6.15 \pm 0.05$ & $6.15 \pm 0.05$ \\
$\mathbf{5}$ & $7.35 \pm 0.10$ & $7.30 \pm 0.35$ \\
$\mathbf{6}$ & $8.50 \pm 0.12$ & $8.45 \pm 0.15$ \\
\hline
\end{tabular}

Superscripts $a, b$ mean on the same row with different superscripts are significantly $(p<0.05)$ different.

\section{Gestation period}

All animals on both the control and the test groups were bred naturally. Test ewes were starved in the $16^{\text {th }}$ week of pregnancy. Gestation period in the test animals lasted for $149 \pm 1$ days while those in the controls carried their pregnancy for 147士 2 days. Parturition was observed to be normal and without assistance. The small variation in pregnancy during that exists in this study might be due to genetic or other locality effect and not as a result of the 7 days starvation treatment of this nature. However, low nutrition in the last trimester of pregnancy has been observed (Loos et al., 2001; Jane et. al., 2007) to increase gestation length.

The summary of the weekly weight of lambs delivered by both the control and test pregnant ewes is shown in Table 5. At birth the mean weight of lambs from the test animals was $2.05 \pm$ $0.05 \mathrm{~kg}$ compared to that of the controls $(2.25 \pm$ $0.01 \mathrm{~kg})$. in this experiment therefore, a mean loss of $1.22 \mathrm{~kg}$ in the body weight of the ewe on a seven day fast in the first week of the last trimester led to a significant loss $(P<0.05)$ in the mean birth weight of lambs by $8.89 \%$ relative to that of the control ewes which had $1.30 \mathrm{~kg}$ gain over the same period. Also, a continuous supremacy in the weights of lambs from the control over those on test, a week after parturition was noted. However, there was no significant difference $(P>0.05)$ observed as at 2 weeks after male lambs were not observed to be heavier than the females in the test group of this study. In spite of these differences in birth weight of lamb as observed in this experiment, there was no advantage in subsequent growth of lambs from the control over those of the test animals, which were starved during pregnancy. Poindron et al., (2007) also reported similar observation and concluded that extremely low level of nutrition of ewes during the later stages of pregnancy such that no gain in weight was made, failed to produce any appreciable effect upon the subsequent growth of lambs.

\section{Conclusion}

It is conventional to witness mass movement of animals from one part of the country to the other by road or rail. This period, no matter how short, is full of stress in which animals witness starvation and lack of water. This present study has been able to highlight and document the possible change in live weight, feed intake and 
Eniolorunda and Adewale (2016) Bang. J. Anim. Sci. 45 (2): 35-40

appetite, rate of recovery and other reproduction performances when pregnant ewes were subjected to such stress of mobilization or transit for sale. A live weight loss of $3.20 \%$ was observed during the starvation period. However, when losses in weight are spread over thousands

\section{References}

AOAC (2002). Official of analysis Association of analytical chemistry official method of analysis. $18^{\text {th }}$ edition Washington D.C. USA

Dwyer, CM (2008). Genetic and physiological determinants of maternal behavior and lamb survival; implications for low-input sheep management. Journal of Animal Science. 86:246-258

Dwyer, CM, Lawrence, AB, Bishop, SC, Lewis, M (2003). Ewe lamb bonding behaviors at birth are affected by maternal under-nutrition in pregnancy. The British Journal of Nutrition, 89:123-136.

Eniolorunda, OO, Fashina, OE and Aro, OO (2009). Adaptive physiological response to load time stress during transportation of cattle in Nigeria. Archivos de Zootecnia 58, 222: 223-230.

Esugbohungbe, OO and Adeleye, IOA (2003). Effect of restriction and feeding on performance in weaner lambs. Trop. Journal of Animal Sciences, 6(1):77-80.

Fahey, AJ, Brameld, JM, Parr, T and Buttery, PJ (2005). The effect of maternal under nutritional before muscle differentiation on the muscle fiber development of the new born lamb. J. Anim. Sci., 83:2564-2571.

Jane, KC, Kirsten, RP, James PN, David, EN, Mark, $A H$, and Lucy, RG (2007). The effect of maternal undernutrition in early gestation on gestation length and fetal and postnatal growth in sheep. Pediatric Research, 62 (4): 422-427.

King, GJ and Robertson HA (1974); A two injection schedule with prostaglandin $\mathrm{F}_{2 a}$ for the regulation of the ovulatory cycle of cattle. Theriogenology, 1:123-128.

Kirton, AH, Paterson, DJ, and Duganzich, DM (1972). Effect of pre-slaughter starvation in cattle. Journal of Animal Science. 34:555-559.

Laporte-Broux, B, Roussel, S, Ponter, A, Perault, J, Chavatte-Palmer, $\mathrm{P}$ and Duvaux-Ponter, $\mathrm{C}$ (2011). Short term effects of maternal feed restriction during pregnancy on goat kid morphology, metabolism, and behavior. J. Anim. Sci., $\quad 89: 2154-2163$.

Lauderdale, JW (1972). Effects of $\mathrm{PGF}_{2 a}$ on pregnancy and estrous cycle of cattle. J. Anim. Sci., 35:246 (Abstr). sheep which are brought down from one part of the country to the other for slaughter over a long distance, the monetary losses can be appreciable. Also, substantial amount of money would be required in terms of labour and materials to realiment these animals.

Loos, RJ, Derom, C, Eeckels, R, Derom, R, Vlietinck, $R$ (2001). Length of gestation and birth weight in dizygotic twins. Lancet, 358:560561

Louis, TM, Hafs, HD and Morrow, DA (1972). Estrus and ovulation after uterine $\mathrm{PGF}_{2 \mathrm{a}}$ in cows. $\mathrm{J}$. Amin. Sci. 35:247 (Abstr)

Mc Donald, P., Edwards, RA, Greehalghalgh, JE (1995). Animal Nutrition, $5^{\text {th }}$ Edition, Longman, London. pp 60-95.

Mutassim, MA (2007). The effect of high calcium intake by pregnant Awassis ewes at late gestation on mineral status and performance of ewes and newborn lambs. Livestock Science, 177:15-23.

Onakomaiya, So, Oyesiku, K.A, and Jegede, SJ (1992). Ogun State in Maps. First ed. Rex. Charles publication, Ibadan

Poindron, P, Levy, F, Keller, M (2007). Maternal responsiveness and maternal selectivity in domestic sheep and goats; the two facet of maternal attachment. Development psychobiology, 49:54-70

Robinson, JJ (1990). Nutrition in the reproduction of farm animals. Nutrition Research Reviews, 3:253-276

Robinson, JJ, Mc Evoy, TG, Sinchair, KD (1999). Nutritional effects on foetal growth. Animal Science, 68: 315-331.

Roche, J.F (1977). Vet. Res. Com, 1:121-129

Rook, JS (2000). Pregnancy toxemia of ewe, does and beef cows. Vet. Clin. North Am. Food Anim. Pract. 16:293-317.

Rowson, LE, Tervit; AR and Brand, A (1972). The use of prostaglandin for synchronization of oestrus in cattle. J. Repord. Fertil. 29:145154

SAS, (2002). Statistical Analysis System. SAS Stat. version 9. SAS Institute Inc. Garry, NC., USA.

Snowder, GD and Glimp, HA (1991). Influence of breed, number of suckling lamb and stage of lactation on ewe milk production and lamb growth under range condition. J. Anim. Sci. 69:923-930.

Vonnahme, KA, Hess, BW and Hansen, TR (2002). Maternal undernutrition for early to midgestation lead to growth retardation, cardiac ventricular hypertrophy andincreased live weight in foetal sheep. Biol. Reprod. 69:133-140. 